\title{
DECISION SUPPORT MODEL FOR SELECTING AND EVALUATING SUPPLIERS IN THE CONSTRUCTION INDUSTRY
}

\author{
Fernando Schramm ${ }^{1}$ and Danielle Costa Morais $^{2 *}$ \\ Received October 23, 2011 / Accepted July 20, 2012
}

\begin{abstract}
A structured evaluation of the construction industry's suppliers, considering aspects which make their quality and credibility evident, can be a strategic tool to manage this specific supply chain. This study proposes a multi-criteria decision model for suppliers' selection from the construction industry, as well as an efficient evaluation procedure for the selected suppliers. The model is based on SMARTER (Simple Multi-Attribute Rating Technique Exploiting Ranking) method and its main contribution is a new approach to structure the process of suppliers' selection, establishing explicit strategic policies on which the company management system relied to make the suppliers selection. This model was applied to a Civil Construction Company in Brazil and the main results demonstrate the efficiency of the proposed model. This study allowed the development of an approach to Construction Industry which was able to provide a better relationship among its managers, suppliers and partners.
\end{abstract}

Keywords: construction industry, multi-criteria decision aid, supplier selection.

\section{INTRODUCTION}

Construction industry managers do not usually develop knowledge about either opportunities or threats; thus, they can neither identify nor align the internal needs of the company with those of their customers. As a consequence, when the purchase managers establish a negotiation process with their suppliers, they usually assign higher importance to the criteria, which are directly related to the product price and delivery objectives. This behavior was verified by Verma and Pullman (1998), whose research results indicated that although managers say that quality is the most important attribute to select a supplier, they actually choose suppliers based largely on the product price and delivery performance. This limitation of the negotiation process undermines the achievement of other goals and, paradoxically, affects the profitability of the business.

Wu et al. (2010) and Ho et al. (2010) emphasize in recent research that the supplier selection decision in a supply chain must not depend solely on product price or quality measures. According

\footnotetext{
*Corresponding author

${ }^{1}$ Federal University of Campina Grande, PB, Brazil. E-mail: fernandoschramm@globo.com

${ }^{2}$ Federal University of Pernambuco, PE, Brazil. E-mail: dcmorais@ufpe.br
} 
to Dickson (1966) there are several parameters used by companies to qualify their suppliers. The author suggests that to carry out this task the following performance evaluation criteria should be considered: quality of input, meeting the deadline for delivery, fulfilling volume of input, competitiveness in terms of the price established by the market and quality in services. Therefore, he proposed twenty-three criteria for the selection of suppliers.

Schmidt et al. (2001) observed that the supply chain of construction industry at Brazil is considered obsolete by many analysts from several areas (mainly in engineering and management sciences). They believe that one reason could be the poor technological development of some parts of the chain, such as the ones located at the construction site. The authors point out the increasing of the need for integrating the processes and operations of a construction company and its suppliers.

Jobim Filho (2002) claims that some characteristics could contribute to the poor integrating and managing of the supply chain of construction industry at Brazil. Based on this information the author argues that the construction industry should consider other criteria, beyond costs, to select and evaluate its suppliers.

- The large number of materials involved in the production process;

- The variety of materials and components which make up the construction industry, each with their own distinct characteristics;

- The lack of information about all suppliers and customers involved in each supply chain makes it difficult to integrate and manage multiple key processes between companies;

- The lack of knowledge about customers' needs and the importance of this information being gathered and passed along the chain;

- The difficulty in integrating processes, since in the construction industry they are different from other industries. For instance, they cannot be considered as being similar to a car manufacturing company.

In this sense, a multi-criteria analysis can be an important tool to support decision related with suppliers' selection, in which multiple criteria are being considered. This kind of analysis support decision-makers in organizing and synthesizing such information in a way which leads them to feel comfortable and confident about making a decision, guaranteeing that all criteria involved in the decision process will be properly taken into account (Belton \& Stewart, 2002). It has been widely used to improve management in the supply chain throughout, as can be seen in Weber et al. (1991), Holt (1998), Degraeve et al. (2000), De Boer et al. (2001) and Ho et al. (2010). These authors performed a wide literature review of the application of multi-criteria analysis for supplier selection. Moreover, De Boer \& Van der Wegen (2003) presented an attempt to assess more effectively the perceived merit of using formal decision tools and approaches for supplier selection in practice.

In this study, different criteria were considered to evaluate and select suppliers in order to increase the quality of the integration and management of this specific chain. Then, a model is proposed 
based on multi-criteria analysis to support the decision-making process in selecting and evaluating suppliers for construction industry. The model uses the multi-criteria method SMARTER (Simple Multi-Attribute Rating Technique, Exploiting Ranking) developed by Edwards \& Barron (1994). The model was applied to a construction company in Brazil.

This paper is structured as follows: Section 2 presents some fundaments of multi-criteria decision aid and the SMARTER method; Section 3 describes the multi-criteria decision support model for selecting and evaluating suppliers in construction industry; Section 4 describes an application of the proposed model; and in Section 5, the conclusions are drawn.

\section{MULTI-CRITERIA DECISION AID}

In most everyday situations, managers need to take decisions that require the evaluation of several alternatives according to different criteria, which make the decision environment complex. Multicriteria analysis is a powerful framework to support this kind of decision. It consists of untangling large problems into discrete components; evaluating these components; reintegrating them; and using the results to construct the decision (Farrell, 1996).

Vincke (1992) and Roy (1996) define a multi-criteria decision problem as being a situation in which, having defined a set A of actions and a family $\mathrm{F}$ of criteria, the decision maker wishes: to determine a subset of actions considered to be the best with respect to F (choice problem); to divide A into subsets according to some norms (sorting problem); to rank the actions of A from the best to worst (ranking problem); to describe actions and their consequences in a formalized and systematic manner, so that decision-makers can evaluate those actions (description of issue).

The specialists divide the multi-criteria decision support method into three families, whose purpose is to bring the approaches together according to some general features of affinities, namely: (i) multiple attribute theory; (ii) outranking methods; (iii) interactive methods. Roy (1996) classifies them as follows: (i) unique synthesis criterion approach, eliminating any incomparability; (ii) outranking synthesis approach, accepting incomparability; (iii) interactive local judgment approach, with trial-error interaction.

- Unique synthesis criterion approach: This is also referred to as the American School. It consists of aggregating the different points-of-view into a unique function which will be optimized. Examples: MAUT (Multi-Attribute Utility Theory) (Keeney \& Raiffa, 1976), SMART (Simple Multi-Attribute Rating Technique) family (Edwards, 1977; Edwards \& Barron, 1994; Mustajoki et al., 2005; Valois \& Almeida, 2009; Gomes et al., 2011) and AHP (Analytic Hierarchy Process) (Saaty, 1988);

- Outranking synthesis approach: This is also referred to as the European School. It consists in the development of a relationship called an outranking relationship, which represents the decision-maker's preferences, the relationship being explored in order to help the decisionmaker solve his/her problems. Examples: ELECTRE (Elimination and Choice Translating Algorithm) (Belton \& Stewart, 2002; De Boer et al., 1998; Roy, 1996; Vincke, 1992) 
and PROMETHEE (Preference Ranking Organization Method for Enrichment Evaluation) (Brans \& Vincke, 1985; and some applications in Behzadian et al., 2010);

- Interactive local judgment approach: this proposes methods which alternate calculation steps, giving successive compromising solutions, and dialog steps, leading to an extra source of information on the decision-maker's preferences (Clímaco et al., 2003; and Vincke, 1992).

The multi-criteria analysis has been used to support different decisions related with the supply chain area: Nagurney et al. (2005) used multi-criteria technique to develop a supply chain network model in which both physical and electronic transactions are allowed and in which supply side risk as well as demand side risk are included in the formulation; Alencar and Almeida (2008) proposed a multi-criteria group decision model for suppliers' selection which is based on ELECTRE IV and VIP Analysis methods and it is applied in those cases where there is a great divergence among the decision makers; Kull \& Talluri (2008) used it to manage the risk in supply chains; through AHP multi-criteria method, Ting \& Cho (2008) identified suppliers and then used a multi-objective linear programming (MOLP) model, considering multiple objectives and constraints, to allocate the optimum order quantities to the suppliers; Cruz (2008) and Cruz (2009) used multi-criteria analysis to measure the impact of corporate social responsibility in supply chain management; Using a -fyzzy approach, Ordoobadi (2009) proposed a multi-criteria model that incorporates decision maker's subjective assessments; Tuzkaya et al. (2009) evaluated the environment performance of suppliers through a multi-criteria analysis; Kirytopoulos et al. (2010) proposed a meta-model for supplier evaluation and order quantity allocation, based on a Multi-Criteria Decision Making (MCDM) method, namely the Analytic Network Process (ANP) and a multi-objective mathematical programming method (MOMP), the AUGMECON (Augmented $\varepsilon$-constraint Method).

It is worth to notice that the multi-criteria methods can be classified according to the meaning of criteria weights. When weighting leads to trade-offs amongst criteria, methods are compensatory, which allows for a disadvantage in some criteria to be compensated by a large advantage in another criterion. When the weights mean relative importance coefficients only, methods are non compensatory, and thus avoid trade-offs amongst criteria. Usually, the suppliers of construction industry do not present a considerable difference in their performance, and the evaluations of them in relation to a set of criteria are very similar. For this reason, a compensatory method seems to be very suitable to decision problems in which the alternatives are suppliers of construction industry. Compensatory multi-criteria methods, such as SMARTER method, have constant of scale, $w_{k}$, that represents trade-offs among criteria; however, in the literature about SMARTER, the term weight is used instead of constant of scale.

The SMARTER is a compensatory method, which is based on the fundamentals of MAUT; however, the procedure for elicitation of parameters is easier than the elicitation procedure of MAUT. This method is more suitable for practical application, especially when the decision makers are ordinary users of this kind of support decision methods. Therefore, one extra advantage of the 
SMARTER is related to the fact that the decision makers find it easy to understand the concepts and parameters inherent in the method, which makes the preference modeling natural and, consequently, increases the effectiveness of applying the methods.

\subsection{SMARTER}

The SMARTER is a method proposed by Edwards (1977), whose main goal is to assess the multiattribute value of alternatives in a decision-making process and to offer a ranking of alternatives from best to worst. The multi-attribute value for an alternative $a$ is given by:

$$
v(a)=\sum_{k=1}^{K} w_{k} v_{k}(a)(k=1,2, \ldots, K),
$$

where $K$ is the number of criteria.

The SMARTER method is divided into nine steps, which includes the first six steps of SMART method, the seventh step of SMARTS (Simple Multi-Attribute Rating Technique, Swing of weights) method and one extra step. The seventh step of SMARTS corrects the intellectual error of SMART, defining a ranking of criteria according to their relative importance (Edwards \& Barron, 1994); and the extra step of SMARTER establishes the weight value of a criterion according to its respective importance which is based on the swing weights and Rank Order Centroid (ROC) approach (Edwards \& Barron, 1994 and Barron \& Barrett, 1996). The analysts should use this approach to define the values of the weights for each criterion, according to the point-of-view of the decision makers. At the end, the method provides a ranking of alternatives ordered from the best to worst in accordance with their respective multi-attribute value. This method also uses the strategy of heroic approximation, provided by SMART method, in order to define the decision maker preferences as well as to justify the linear approximation of a single-dimensional value function and the use of an additive aggregation model.

In multi-criteria decision problems, a decision is dependent on decision-maker's preference in all criteria considered. A traditional way to handle this kind of problem involves characterizing primarily the preferences with a utility function as established in the MAUT. In this sense, the decisions are made based on utility functions for different criteria. However, Lai et al. (2004) and Lai et al. (2006) emphasize that it is not trivial to define each utility function for all criteria related to the problem as established in the MAUT, especially when there are conflict in the preferences of multiple criteria, i.e., how much an individual is willing to lose in one criterion to win in another or vice versa. This trade-off will affect the multi-criteria utility that a decision maker will get when all criteria are being considered jointly in the multi-criteria decision problem. The preference elicitation process as recommended in the MAUT requires much time and it may be considered intractable. In SMARTER method the trade-off analysis is easier than in MAUT, mainly, because the analyst does not consider the uncertainty when determining the consequences for each alternative (Almeida, 2010) and the trade-off among criteria is established through a natural procedure (the seventh step of SMARTS method) in which the decision maker defines a ranking of criteria according to their relative importance and based on swing weights, 
then, the values of weights are established as proposed in the ROC approach. In that perspective, the SMARTER method, is interested in elaborate a value function.

In the ROC approach proposed by Barron \& Barrett (1996) the weights are calculated according to the following expression:

$$
\begin{aligned}
& \text { If } w_{1} \geq w_{2} \geq \cdots \geq w_{k} \text { then, } \\
& w_{1}=(1+1 / 2+1 / 3+\cdots+1 / K) / K \\
& w_{2}=(0+1 / 2+1 / 3+\cdots+1 / K) / K \\
& w_{3}=(0+0+1 / 3+\cdots+1 / K) / K \\
& w_{k}=(0+\cdots+0+1 / K) / K
\end{aligned}
$$

Usually, if $K$ is the number of criteria, then the weight of the $k$ th criterion is:

$$
w_{k}=(1 / K) \sum_{i=k}^{K}(1 / i)
$$

During the development of the field application, it was possible to detect that the decisionmaker of the construction company did not have knowledge about multi-criteria decision-aid approaches; thus, it was important to develop a methodology based on simple and easy to use and understand procedures, with a theoretical foundation as well. Therefore, the SMARTER method was chosen to support the evaluating and selecting of suppliers in the supply chain of the construction industry.

\section{THE PROPOSED MODEL}

This section presents a multi-criteria model to support decisions related to the selection of suppliers in the construction industry, as well as the procedure for evaluating the supplier who was selected by the model.

It is important to emphasize that the development of the model was based on a construction company, as well as on information collected in research about the construction industry. In addition, interviews were conducted with the manager responsible for the supply chain or purchasing process, who provided data for performing the model described below.

The model is divided into four steps: (i) definition of suppliers who will participate in the selection process; (ii) definition of criteria set; (iii) application of the multi-criteria method SMARTER; (iv) evaluation of the supplier who was selected (Fig. 1).

\subsection{Definition of suppliers}

Due to the variety of materials and components, which integrate the supply chain of construction industries, the analyst and the decision-maker (responsible for the purchasing process in this type of business) must verify and order the materials to be used in the selecting process. According to 


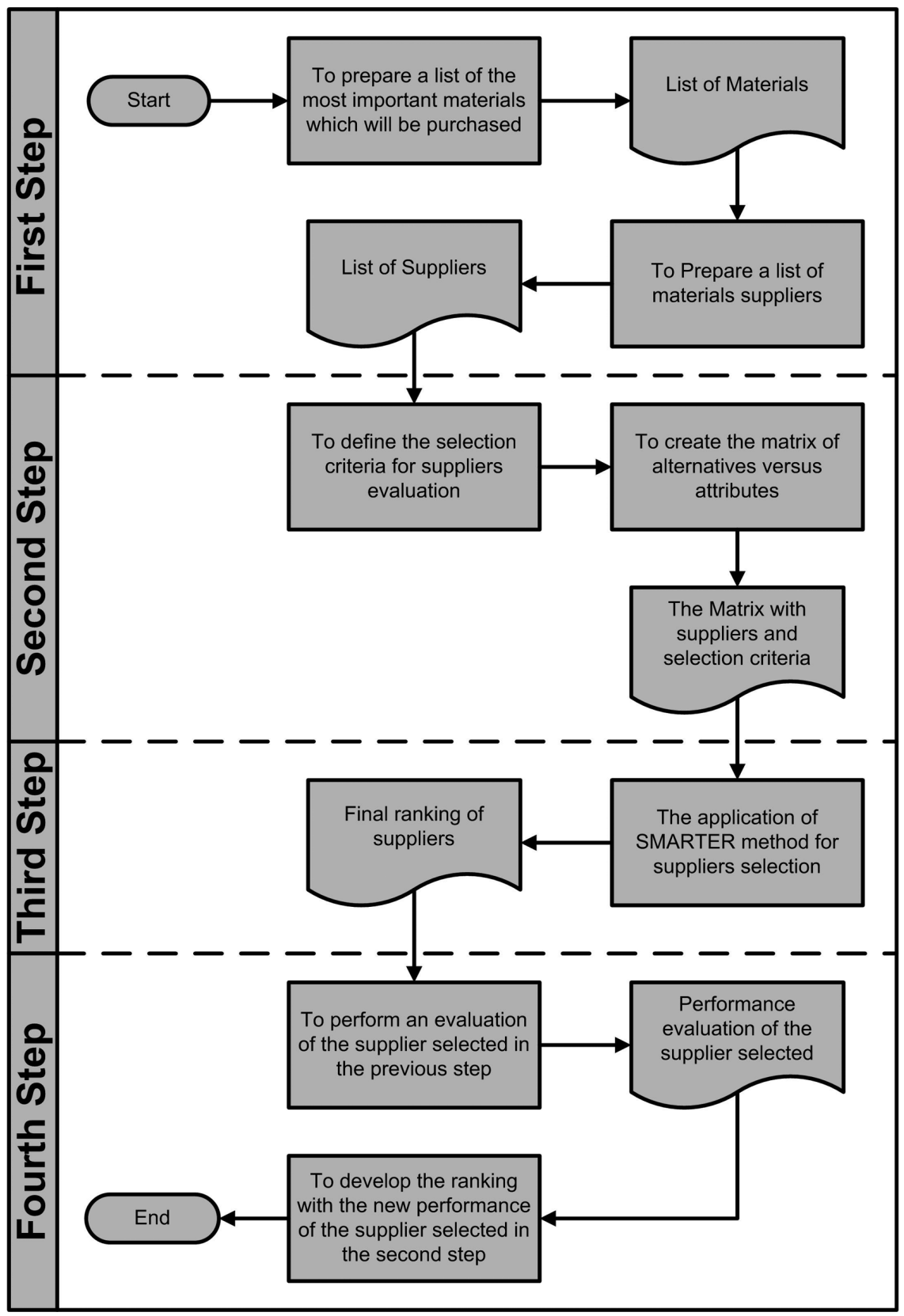

Figure 1 - Steps and procedures of the multi-criteria decision support model.

Szajubok et al. (2006), in order to determine the level of importance of a stored item, companies should evaluate several criteria, and not only the criteria associated with costs. These authors created a model based on ELECTRE TRI to allocate materials into three categories: least important materials, most important materials and materials of intermediate importance. 
If the company already has a procedure for classifying the materials to be used in the construction, then, this procedure must be critically analyzed in order to understand how the company evaluates the level of importance of materials. However, if the procedure does not consider multiple criteria during the classification of materials or if the company doesn't use any procedure, then the classification proposed by Szajubok et al. (2006) should be used.

The company must create a list of materials to be included in a category of very important materials. This category will be considered critical and its management will require special attention. Szajubok et al. (2006) provide an example of a list of materials, which are considered very important.

The procedure will be applied to select and evaluate suppliers for the materials included in the critical category. The decision maker (supply chain or purchase management) must provide a list of these suppliers. There is no restriction about the number of suppliers to be considered by the model.

\subsection{Definition of criteria}

The analyst and the decision-maker must propose the criteria that will be considered in the selecting process and their respective evaluation scales. Chou \& Chang (2008) emphasize that during the criteria formulation stage, the main task for buying firms is to assess the key competitive factors in their industry and translate these dimensions into supplier selection criteria with their respective scales.

In order to support the analyst and decision-maker in the criteria definition phase, the following papers should be used to define the family of criteria: Amid et al. (2006); Bevilacqua et al. (2006); Boran et al. (2009); Bottani \& Rizzi (2008); Chou \& Chang (2008); Dickson (1966); Dulmin \& Mininno (2003); Ng (2008); Ramanathan (2007). These researchers show how the managers responsible for the purchasing process in different types of business can contribute to improving the management in their supply chain throughout. The decision maker can create new criteria according to the need of the business.

To evaluate each supplier according to all criteria considered and to prepare the evaluation matrix, the decision-maker should follow the steps below. These steps are especially useful for new suppliers, who have hitherto never participated in the company's selection of suppliers.

- Visiting the supplier in order to get the necessary information to evaluate him according to all criteria considered;

- Sending an order to the supplier beforehand, in order to evaluate this supplier according to all criteria considered;

- Asking a competitor or a client who has already bought something from the supplier about that experience in order to get the necessary information, which will be useful to evaluate the supplier;

- Asking the supplier for a self-evaluation according to all criteria considered by the company. 


\subsection{Application of multi-criteria method}

The method SMARTER is applied according to the steps described in Edwards \& Barron (1994), thus producing a ranking of suppliers. The supplier in the highest position should be selected.

\subsection{Evaluation of the supplier}

This step provides an evaluation of the supplier who was selected by the multi-criteria method. This evaluation should be conducted after the delivery of the material. This step provides a continuous evaluation of suppliers and considers all criteria and their respective levels of importance. Moreover, this increases the competitive advantage of the company and supplier over their respective markets and improves the quality of the relationship between client and supplier.

This step introduces a mechanism for measuring the supplier's performance level after supplying materials. It is important to develop a management procedure for storing the information needed to evaluate the supplier in this step. The commonly used procedures are:

- Inspection during delivery: a checklist can be used;

- Management reports containing information on the location of the construction;

- Questionnaires containing questions that enable the supplier's performance to be measured. This procedure can be undertaken after the construction has been concluded.

- Interviewing stakeholders who participated directly in the construction.

It is important to note that this information must be stored in the company's database to be used as input for a subsequent selection process, especially in situations where the selected supplier can supply other materials.

This evaluation procedure produces a performance index, which shows the improvement in the quality of the relationship between the company and its suppliers. A better relationship will improve the satisfaction of end-of-the-line customers with regard to the products and services offered.

The evaluation of the selected supplier will be based on a multi-attribute value constructed from the performance of him/her over the set of criteria considered. This multi-attribute value provides the information which will be used by the decision maker to decide about perform a new selection process or continue with the supplier who was selected in the previous selection.

The construction of supplier's multi-attribute value must be conducted according to the following rules: the performance of supplier $h(h=1,2, \ldots)$ in each criterion must be put in the "Real Value" column in Table 1; to calculate the "Normalized Value" column, the analyst and the decision-maker must verify the value function which is associated with each criterion according to Edwards \& Barron (1994); the multi-attribute value is calculated according to the expression in "Multi-attribute value" column. 
Table 1 - Performance of selected supplier.

\begin{tabular}{|c|c|c|c|c|c|}
\hline \multirow{2}{*}{$\begin{array}{c}\text { Attribute } \\
\text { (k) }\end{array}$} & \multirow{2}{*}{$\begin{array}{l}\text { Weight } \\
\text { ROC }\end{array}$} & \multirow{2}{*}{$\begin{array}{l}\text { Performance in } \\
\text { selection } \\
\text { process }\end{array}$} & \multicolumn{3}{|c|}{ Selected supplier's performance } \\
\hline & & & $\begin{array}{l}\text { Real } \\
\text { value }\end{array}$ & $\begin{array}{c}\text { Normalized } \\
\text { value }\end{array}$ & $\begin{array}{l}\text { Multi-attribute } \\
\text { value }\end{array}$ \\
\hline \multirow{2}{*}{$1 \mathrm{st}$} & \multirow{2}{*}{$w_{1}$} & Best $=x_{h 1}^{*}$ & \multirow{2}{*}{$x_{h 1}$} & \multirow{2}{*}{$x_{h 1}^{\prime \prime}$} & \multirow{2}{*}{$w_{1} \cdot x_{h 1}^{\prime \prime}$} \\
\hline & & Worst $=x_{h 1}^{\prime}$ & & & \\
\hline \multirow{2}{*}{ 2nd } & \multirow{2}{*}{$w_{2}$} & Best $=x_{h 2}^{*}$ & \multirow{2}{*}{$x_{h 2}$} & \multirow{2}{*}{$x_{h 2}^{\prime \prime}$} & \multirow{2}{*}{$w_{2} \cdot x_{h 2}^{\prime \prime}$} \\
\hline & & Worst $=x_{h 2}^{\prime}$ & & & \\
\hline \multirow{2}{*}{3 rd } & \multirow{2}{*}{$w_{3}$} & Best $=x_{h 3}^{*}$ & \multirow{2}{*}{$x_{h 3}$} & \multirow{2}{*}{$x_{h 3}^{\prime \prime}$} & \multirow{2}{*}{$w_{3} \cdot x_{h 3}^{\prime \prime}$} \\
\hline & & Worst $=x_{h 3}^{\prime}$ & & & \\
\hline \multirow{2}{*}{$k$-th } & \multirow{2}{*}{$w_{k}$} & Best $=x_{h k}^{*}$ & \multirow{2}{*}{$x_{h k}$} & \multirow{2}{*}{$x_{h k}^{\prime \prime}$} & \multirow{2}{*}{$w_{k} \cdot x_{h k}^{\prime \prime}$} \\
\hline & & Worst $=x_{h k}^{\prime}$ & & & \\
\hline & & & \multicolumn{3}{|c|}{ Overall score $=\sum_{k=1}\left(w_{k} \cdot x_{h k}^{\prime \prime}\right)$} \\
\hline
\end{tabular}

If the value of the current supplier does not decrease, then a new selection process is not necessary. Otherwise, the decision maker should perform a new selection through the multi-criteria model.

\section{APPLICATION OF THE METHODOLOGY}

This section presents a real application, in which the decision support model or methodology was applied to aid the decision-maker (the person responsible for the purchasing process) of a construction company in Recife, Pernambuco, Brazil. The proposed methodology was developed and applied during the construction of a vertical building.

The model supported the procurement manager in taking decisions about selecting and evaluating suppliers. The way the model was structured made the set of suppliers, what criteria were being considered and what performance indices were being used during the process clear to him.

Moreover, the model establishes the strategic policies, which guide the stakeholders in the supply chain. These policies provide an increase in competitiveness, since suppliers know the reasons why they won or lost an order.

\subsection{Defining the suppliers}

The decision-maker did not have any procedure for classifying materials. Therefore, a list of the most important materials, obtained from Szajubok et al. (2006), was presented to him. The decision-maker decided to apply the model to materials for which there were at least four suppliers. Table 2 gives the list of the materials and which suppliers were selected and evaluated using the model. The model was applied to select suppliers of M08 material only. The suppliers are 
Table 2 - List of materials and its respective suppliers.

\begin{tabular}{|l|l|l|}
\hline \multicolumn{2}{|c|}{ Materials } & \multicolumn{1}{c|}{ Suppliers' code } \\
\hline Code & \multicolumn{1}{|c|}{ Description } & \\
\hline M08 & Multi-use mortar & F01.M08; F02.M08; F03.M08; F04.M08; F05.M08. \\
\hline M34 & Planks & F12.M34; F13.M34; F14.M34; F15.M34; F16.M34. \\
\hline M36 & Circuit breaker & F06.M36; F07.M36; F08.M36; F09.M36. \\
\hline M37 & Electricity switch-boards & F06.M37; F07.M37; F08.M37; F10.M37; F11.M37. \\
\hline
\end{tabular}

represented by a code, described as follows: FXX.MYY: "F" for supplier; and XX for supplier number; "M" for material; and YY for material number.

\subsection{Defining the criteria}

In this step, the set of criteria was defined. Firstly, the analyst gave the decision-maker a previously drawn up list, made after the first meeting in his office. Secondly, the decision-maker defined what criteria would be considered. He considered all criteria presented by the analyst, but changed one of them (Quality to Quality Management System - QMS) and included another (Rejection level). The criteria considered and their respective scales were built and they are presented in Tables 3 and 4, respectively.

Finally, the analyst defined the matrix of alternatives (suppliers) and criteria. The evaluation of M08 material is presented in Table 5.

\subsection{Application of the method}

Firstly, a visual inspection verified that there are no dominant alternatives.

Then, the relative importance among attributes was obtained. To obtain this relative importance, the decision-maker was asked the following question, which is based on Edwards \& Barron (1994): Suppose you have an extra alternative whose performance is the worst in all the criteria considered. You are given the opportunity to improve the performance of this alternative in one criterion only. Which criterion would you choose first? Which would be the next criterion that you would choose?

The question was repeated until all criteria had been chosen. Based on the sequence of criteria chosen, the importance ranking of the criteria was defined (Table 6). After that, the onedimensional values present in Table 5 were normalized.

In relation to the criteria weights, they were established following the SMARTER multi-criteria method. This method has a stage for exploring the ranking of the criteria in order to define the weight of each criterion according to its relative importance (ROC weights), Edwards \& Barron (1994). The ROC weights and the normalized matrix of one-dimensional values were used to calculate the multi-attribute value for each alternative. The normalized matrix for M08 material is presented in Table 7 . 
Table 3 - Criteria and their respective descriptions.

\begin{tabular}{|c|c|c|}
\hline ID & Criteria & Description \\
\hline $\mathrm{C} 1$ & $\begin{array}{l}\text { Quality Management } \\
\text { System - QMS }\end{array}$ & $\begin{array}{l}\text { This is measured by the level of supplier performance in } \\
\text { relation to the certification of the quality management } \\
\text { system. If the supplier has developed some practices } \\
\text { in their QMS, the construction company can evaluate } \\
\text { them. The following aspects are considered in the eval- } \\
\text { uation: involvement of top management; quality policy; } \\
\text { quality manual; standard operating procedures; quality } \\
\text { records; how customer satisfaction is measured. }\end{array}$ \\
\hline $\mathrm{C} 2$ & Unit price & This is based on the monetary value of the material. \\
\hline $\mathrm{C} 3$ & Cost reduction plans & $\begin{array}{l}\text { This evaluates the contribution of improvement projects } \\
\text { that are already being deployed or that will be imple- } \\
\text { mented, which must cause direct impact on the cost of } \\
\text { materials; as a result, suppliers can offer a reduction in } \\
\text { the price of items. The term improvement project is re- } \\
\text { lated to investments in new management or equipment } \\
\text { technologies to reduce costs. }\end{array}$ \\
\hline $\mathrm{C} 4$ & Transport costs & $\begin{array}{l}\text { This is based on the monetary value with regard to trans- } \\
\text { porting the materials. }\end{array}$ \\
\hline $\mathrm{C} 5$ & Rejection level & $\begin{array}{l}\text { This is related to the total number of orders for materi- } \\
\text { als returned to suppliers by the company. Due to prob- } \\
\text { lems of dependability of the specific standard of mate- } \\
\text { rials and delivery delays being detected, orders are re- } \\
\text { turned. }\end{array}$ \\
\hline C6 & $\begin{array}{l}\text { Request for } \\
\text { assistance answered }\end{array}$ & $\begin{array}{l}\text { This is measured by the relationship between the num- } \\
\text { ber of requests for assistance sent to the supplier and the } \\
\text { number effectively answered. }\end{array}$ \\
\hline C7 & Lead time & $\begin{array}{l}\text { The period of time between placing a purchase order } \\
\text { and receipt of the ordered items. }\end{array}$ \\
\hline $\mathrm{C} 8$ & Time flexibility & $\begin{array}{l}\text { This is related to the changes the construction company } \\
\text { needs to make in its order system as far as delivery time } \\
\text { is concerned. }\end{array}$ \\
\hline C9 & Quantity flexibility & $\begin{array}{l}\text { This is related to the changes the construction company } \\
\text { needs to make in its order system as far as the amount } \\
\text { of items requested is concerned. }\end{array}$ \\
\hline
\end{tabular}


Table 4 - Scales for evaluating each criterion.

\begin{tabular}{|ll|}
\hline ID & \multicolumn{1}{c|}{ Evaluation scale } \\
\hline C1 & $\begin{array}{l}\text { Sum of the number of standard operating procedures, the number of preventative actions and } \\
\text { the number of training events. }\end{array}$ \\
\hline C2 & R \$ per unit of material measured. \\
\hline C3 & Percentage of reduction in costs offered by the project. \\
\hline C4 & R \$ per kilometer transported. \\
\hline C5 & Percentage of rejection. \\
\hline C6 & Percentage of requests for assistance answered. \\
\hline C7 & The average number of days needed to fulfill an order. \\
\hline C8 & $\begin{array}{l}\text { The average rate of change in the delivery time which was agreed with the supplier but } \\
\text { needed to be changed by the construction company in the last six months. The suggestion is } \\
\text { to evaluate this criterion based on data from the latest six months. }\end{array}$ \\
\hline C9 & $\begin{array}{l}\text { The average rate of change in the quantity of materials requested by the construction com- } \\
\text { pany in orders already placed. The suggestion is to evaluate this criterion based on data from } \\
\text { the latest six months. }\end{array}$ \\
\hline &
\end{tabular}

Table 5 - Matrix of alternatives versus criteria.

\begin{tabular}{|c|c|c|c|c|c|c|c|c|c|}
\hline \multirow[b]{3}{*}{ Alternatives } & \multicolumn{9}{|c|}{ Criteria of evaluation } \\
\hline & \multicolumn{3}{|c|}{ Cost } & \multicolumn{3}{|c|}{ Quality } & \multicolumn{3}{|c|}{ Delivery } \\
\hline & $\begin{array}{l}\text { Unity } \\
\text { price }\end{array}$ & $\begin{array}{c}\text { Transport } \\
\text { costs }\end{array}$ & $\begin{array}{c}\text { Cost } \\
\text { reduction } \\
\text { plan }\end{array}$ & $\begin{array}{c}\text { Rejection } \\
\text { level }\end{array}$ & $\begin{array}{c}\text { Requests } \\
\text { answered }\end{array}$ & QMS & $\begin{array}{l}\text { Lead } \\
\text { time }\end{array}$ & $\begin{array}{c}\text { Time } \\
\text { flexibility }\end{array}$ & $\begin{array}{l}\text { Quantity } \\
\text { flexibility }\end{array}$ \\
\hline F01.M08 & $\mathrm{R} \$ 10.95$ & $\mathrm{R} \$ 1.10$ & $2.50 \%$ & $7.60 \%$ & $81 \%$ & 48 & 5 & $70 \%$ & $15 \%$ \\
\hline F02.M08 & $\mathrm{R} \$ 7.70$ & $\mathrm{R} \$ 1.85$ & $2.13 \%$ & $12.30 \%$ & $88 \%$ & 36 & 7 & $24 \%$ & $58 \%$ \\
\hline F03.M08 & $\mathrm{R} \$ 8.63$ & $\mathrm{R} \$ 1.17$ & $0.80 \%$ & $8.70 \%$ & $53 \%$ & 47 & 18 & $68 \%$ & $65 \%$ \\
\hline F04.M08 & $\mathrm{R} \$ 7.19$ & $\mathrm{R} \$ 1.43$ & $2.47 \%$ & $7.93 \%$ & $92 \%$ & 9 & 10 & $64 \%$ & $61 \%$ \\
\hline F05.M08 & R\$ 8.97 & $\mathrm{R} \$ 1.50$ & $2.35 \%$ & $8.15 \%$ & $95 \%$ & 44 & 8 & $73 \%$ & $18 \%$ \\
\hline
\end{tabular}

Table 6 - The importance ranking of the criteria.

\begin{tabular}{|l|c|}
\hline \multicolumn{1}{|c|}{ Criteria } & $\begin{array}{c}\text { Importance } \\
\text { ranking }\end{array}$ \\
\hline QMS & 1 \\
Unit price & 2 \\
Cost reduction plans & 3 \\
Transport costs & 4 \\
Rejection level & 5 \\
Request for assistance answered & 6 \\
Lead time & 7 \\
Time flexibility & 8 \\
Quantity flexibility & 9 \\
\hline
\end{tabular}




\begin{tabular}{|c|c|c|c|c|c|c|c|}
\hline$\stackrel{\stackrel{!}{E}}{\stackrel{\Xi}{\Sigma}}$ & 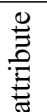 & $\frac{\mathscr{g}}{\overparen{D}}$ & $\begin{array}{l}\text { Lั } \\
\text { 잉 }\end{array}$ & $\begin{array}{l}\text { ஜํ. } \\
\stackrel{0}{0} \\
\stackrel{0}{0}\end{array}$ & $\begin{array}{l}\frac{m}{3} \\
\stackrel{6}{0}\end{array}$ & 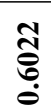 & $\begin{array}{l}\stackrel{0}{0} \\
\stackrel{0}{0} \\
\stackrel{0}{0}\end{array}$ \\
\hline \multirow{9}{*}{ 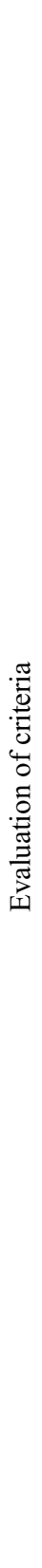 } & iे & $\begin{array}{l}\tilde{a} \\
\tilde{0} \\
0 \\
\| \\
\vdots \\
\hat{\jmath}\end{array}$ & $\begin{array}{l}8 \\
0 \\
0\end{array}$ & $\begin{array}{l}8 \\
\infty \\
\infty \\
0\end{array}$ & $\underset{-}{\stackrel{0}{0}}$ & $\begin{array}{c}\text { ڤ్ } \\
\text { o }\end{array}$ & $\begin{array}{l}8 \\
\stackrel{0}{0} \\
0\end{array}$ \\
\hline & $\stackrel{\infty}{0}$ & 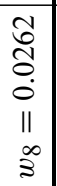 & $\hat{\sigma}$ & $\begin{array}{l}8 \\
\vdots \\
0\end{array}$ & $\begin{array}{l}\stackrel{\infty}{0} \\
\infty \\
0\end{array}$ & $\begin{array}{l}0 \\
\infty \\
0 \\
0\end{array}$ & ¿̊. \\
\hline & $\hat{U}$ & 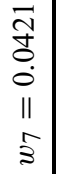 & $\underset{-}{8}$ & \begin{tabular}{l}
0 \\
\multirow{1}{*}{} \\
0 \\
0
\end{tabular} & $\begin{array}{l}8 \\
:\end{array}$ & $\begin{array}{l}n \\
0 \\
0\end{array}$ & $\frac{\mathfrak{0}}{0}$ \\
\hline & ن & $\begin{array}{l} \\
\\
0 \\
0 \\
0 \\
\| \\
\text { ॥. } \\
\vdots\end{array}$ & $\begin{array}{l}\hat{0} \\
\stackrel{0}{0}\end{array}$ & $\begin{array}{l}\tilde{\omega} \\
\hat{0} \\
0\end{array}$ & $\begin{array}{l}8 \\
\vdots \\
0\end{array}$ & ఏे & ¿ \\
\hline & $\approx$ & 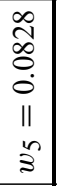 & \& & $\begin{array}{l}8 \\
0 \\
0\end{array}$ & $\begin{array}{l}\stackrel{0}{\circ} \\
\stackrel{0}{0}\end{array}$ & ồ & $\begin{array}{l}0 \\
\infty \\
\infty \\
0 \\
0\end{array}$ \\
\hline & ঠ & 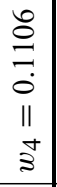 & $\stackrel{8}{8}$ & $\stackrel{8}{8}$ & 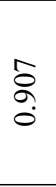 & $\begin{array}{l}8 \\
n \\
0\end{array}$ & 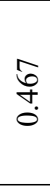 \\
\hline & $\tilde{U}$ & 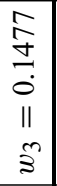 & \& & 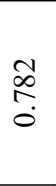 & $\begin{array}{l}8 \\
:\end{array}$ & 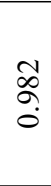 & $\frac{\mathfrak{a}}{\sigma}$ \\
\hline & U & 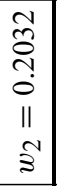 & $\begin{array}{l}8 \\
0 \\
0\end{array}$ & $\begin{array}{l}\mathbb{U} \\
\infty \\
0\end{array}$ & $\begin{array}{l}\tilde{\sigma} \\
\dot{0}\end{array}$ & ¿ & $\begin{array}{l}\hat{n} \\
\tilde{n}\end{array}$ \\
\hline & $\bar{U}$ & $\begin{array}{c}\tilde{g} \\
\tilde{m} \\
0 \\
\| \\
\overrightarrow{3}\end{array}$ & $\stackrel{8}{8}$ & $\begin{array}{l}\tilde{\sigma} \\
0\end{array}$ & 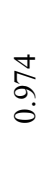 & $\begin{array}{l}8 \\
8 \\
0\end{array}$ & $\begin{array}{l}\hat{\partial} \\
\dot{0} \\
0\end{array}$ \\
\hline & 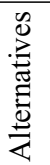 & & $\frac{\sum_{0}^{\infty}}{\stackrel{0}{0}}$ & $\begin{array}{l}\sum_{0}^{\infty} \\
\text { ô } \\
\text { I }\end{array}$ & 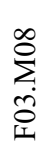 & $\sum_{\substack{+\\
}}^{\infty}$ & $\sum_{\substack{\infty \\
0}}^{\infty}$ \\
\hline
\end{tabular}


Table 8 presents the ranking of suppliers who participated in selecting M08 material.

Table 8 - Ranking related to suppliers of M08 material.

\begin{tabular}{|c|c|c|}
\hline \multicolumn{2}{|c|}{$\begin{array}{c}\text { Ranking of } \\
\text { suppliers }\end{array}$} & $\begin{array}{c}\text { Multi-attribute } \\
\text { value }\end{array}$ \\
\hline 1st & F05.M08 & $\mathbf{0 . 7 6 8 5}$ \\
2nd & F01.M08 & $\mathbf{0 . 7 6 2 6}$ \\
3rd & F03.M08 & $\mathbf{0 . 6 3 1 3}$ \\
4th & F02.M08 & $\mathbf{0 . 6 0 5 6}$ \\
5th & F04.M08 & $\mathbf{0 . 6 0 2 2}$ \\
\hline
\end{tabular}

In the table above, it can be seen that the multi-attribute values for F05.M08 and F01.M08 are very close, the difference being 0.0059 only. Therefore, as both alternatives have approximately the same multi-attribute values and consequently the same competitive advantages, the decisionmaker can choose between F05.M08 and F01.M08 to supply the Multi-use mortar. However, the cost of transportation can be used by the decision-maker to decide between both suppliers. For example, a reduction of 30 cents per kilometer in the cost of transportation by F05.M08 provides the following final ranking (see Table 9).

Table 9 - Ranking related to suppliers of M08 material (modified).

\begin{tabular}{|c|c|c|}
\hline \multicolumn{2}{|c|}{$\begin{array}{c}\text { Ranking of } \\
\text { suppliers }\end{array}$} & $\begin{array}{c}\text { Multi-attribute } \\
\text { value }\end{array}$ \\
\hline 1st & F05.M08 & $\mathbf{0 . 8 1 2 8}$ \\
2nd & F01.M08 & $\mathbf{0 . 7 6 2 6}$ \\
3rd & F03.M08 & $\mathbf{0 . 6 3 1 3}$ \\
4th & F02.M08 & $\mathbf{0 . 6 0 5 6}$ \\
5th & F04.M08 & $\mathbf{0 . 6 0 2 2}$ \\
\hline
\end{tabular}

Given this result, the decision-maker should choose the alternative F05.M08, since it has the best multi-attribute value. A reduction of 30 cents per kilometer in the cost of transportation by F05.M08 results in increasing the difference between F05.M08 and F01.M08 from 0.0059 to 0.0502 , which corresponds to a difference of approximately $5 \%$. The decision-maker can use this analysis to negotiate a reduction in the transportation cost with the suppliers.

\subsection{Evaluating the selected supplier}

The evaluation was not applied to the real situation presented, because measurement of the supplier's performance can only be conducted after the ending of construction. However, a numerical application of this step was performed in order to describe how the supplier's evaluation occurs. 
Firstly, the manager responsible for procurement should compile a spreadsheet with the data collected during the delivery of the material, as per Table 10.

Table 10 - Exemplification for evaluating the selected supplier's performance.

\begin{tabular}{|c|c|c|c|c|c|}
\hline \multirow[b]{2}{*}{$\begin{array}{l}\text { Attribute } \\
\text { (k) }\end{array}$} & \multirow[b]{2}{*}{$\begin{array}{l}\text { Weight } \\
\text { ROC }\end{array}$} & \multirow[b]{2}{*}{$\begin{array}{l}\text { Performance in } \\
\text { selection process }\end{array}$} & \multicolumn{3}{|c|}{ Selected supplier's performance } \\
\hline & & & $\begin{array}{l}\text { Real } \\
\text { value }\end{array}$ & $\begin{array}{c}\text { Normalized } \\
\text { value }\end{array}$ & $\begin{array}{l}\text { Multi- } \\
\text { attribute } \\
\text { value }\end{array}$ \\
\hline \multirow{2}{*}{ QMS } & \multirow{2}{*}{0.31433} & Best $=48$ & \multirow{2}{*}{39} & \multirow{2}{*}{0.7692} & \multirow{2}{*}{0.2418} \\
\hline & & Worst $=9$ & & & \\
\hline \multirow{2}{*}{ Unit price } & \multirow{2}{*}{0.20322} & Best $=\mathrm{R} \$ 7.19$ & \multirow{2}{*}{$\mathrm{R} \$ 8.00$} & \multirow{2}{*}{0.7846} & \multirow{2}{*}{0.1594} \\
\hline & & Worst $=\mathrm{R} \$ 10.95$ & & & \\
\hline \multirow{2}{*}{$\begin{array}{l}\text { Cost reduction } \\
\text { plans }\end{array}$} & \multirow{2}{*}{0.14766} & Best $=2.5 \%$ & \multirow{2}{*}{$1.80 \%$} & \multirow{2}{*}{0.5882} & \multirow{2}{*}{0.0869} \\
\hline & & Worst $=0.8 \%$ & & & \\
\hline \multirow{2}{*}{ Transport costs } & \multirow{2}{*}{0.11063} & Best $=\mathrm{R} \$ 1.10$ & \multirow{2}{*}{$\mathrm{R} \$ 1.20$} & \multirow{2}{*}{0.8667} & \multirow{2}{*}{0.0959} \\
\hline & & Worst $=\mathrm{R} \$ 1.85$ & & & \\
\hline \multirow{2}{*}{ Rejection level } & \multirow{2}{*}{0.08285} & Best $=7.6 \%$ & \multirow{2}{*}{$7.85 \%$} & \multirow{2}{*}{0.9468} & \multirow{2}{*}{0.0784} \\
\hline & & Worst $=12.3 \%$ & & & \\
\hline \multirow{2}{*}{$\begin{array}{l}\text { Request for } \\
\text { assistance answered }\end{array}$} & \multirow{2}{*}{0.06063} & Best $=95 \%$ & \multirow{2}{*}{$95 \%$} & \multirow{2}{*}{1,0000} & \multirow{2}{*}{0.0606} \\
\hline & & Worst $=53 \%$ & & & \\
\hline \multirow{2}{*}{ Lead time } & \multirow{2}{*}{0.04211} & Best $=5$ & 95 & 06538 & 00275 \\
\hline & & Worst $=18$ & 3.0 & 0.0350 & 0.0210 \\
\hline Time flexihility & 002623 & Best $=73 \%$ & $580 \%$ & 06030 & 00182 \\
\hline 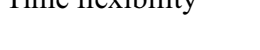 & 0.02025 & Worst $=24 \%$ & $50 \%$ & 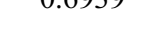 & 0.0102 \\
\hline Puntitu flovibility & 001225 & Best $=65 \%$ & $23 \%$ & 01600 & 00020 \\
\hline 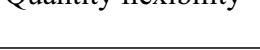 & 0.01200 & Worst $=15 \%$ & & 0.1000 & \\
\hline & & & Ove & all score $=0$ & 707 \\
\hline
\end{tabular}

Based on the table above, the decision-maker can decide not to carry out another selection process. This decision can be reinforced by the information presented in Table 11. Although the multi-attribute value for the F05.M08 supplier decreased from 0.8128 (in the beginning of the supply, see Table 9) to 0.7707 (after the supply, when the decision-maker had already collected the data related to the supply), the new performance shows that they are still in the first position.

At the end of this step, the analyst and the decision-maker should verify if the change in the performance of the alternatives would provoke a change in the relative importance among the criteria or the elimination of some criteria which have a small range among the alternatives. In this case, the criteria weights must be redefined. 
Table 11 - Ranking related to supplier of M08 material.

\begin{tabular}{|c|c|c|}
\hline \multicolumn{2}{|c|}{$\begin{array}{c}\text { Ranking of } \\
\text { suppliers }\end{array}$} & $\begin{array}{c}\text { Multi-attribute } \\
\text { value }\end{array}$ \\
\hline 1st & F05.M08 & $\mathbf{0 . 7 7 0 7}$ \\
2nd & F01.M08 & $\mathbf{0 . 7 6 2 6}$ \\
3rd & F03.M08 & $\mathbf{0 . 6 3 1 3}$ \\
4th & F02.M08 & $\mathbf{0 . 6 0 5 6}$ \\
5th & F04.M08 & $\mathbf{0 . 6 0 2 2}$ \\
\hline
\end{tabular}

\section{CONCLUSIONS}

Construction companies know that it is important to improve the quality of the relationships they have with their suppliers and other partners in the supply chain. However, they do not know how to improve the performance of their suppliers in relation to the needs of the organization. One reason is that a lot of companies do not have time available to discuss management techniques, which can support decisions in this area; another reason is their lack of knowledge about the existence of such techniques.

This study allowed the development of an approach to the construction industry, which was able to provide a better relationship among its managers, suppliers and partners, because in addition to structuring the process of recruitment and selection, it established explicit strategic policies on which the management system of the company relied to make the selection of suppliers. Also, the application of the model made it clear to suppliers and other stakeholders what the main indices considered when evaluating their performance in the construction supply chain were.

Furthermore, it was verified during the study that, to select suppliers, most managers in the construction industry only consider criteria associated with price and quality, not using any formal method to provide a structured evaluation of the selection process, which is essential to guarantee an efficient evaluation. In many situations, these evaluations are only based on the intuition and expertise of the decision-makers.

As a result of the proposed model, it was possible to characterize the selection problem as a multi-criteria problem and thus to identify the main criteria which should be considered to select and evaluate suppliers in the construction industry. Also, it was possible to apply the model to a real situation, showing its adequacy and coherence. Moreover, using the model, the company reduced the risks associated with decision-making in the issue related to selecting suppliers, making it possible to eliminate some subjective aspects related to the purchase of their materials.

\section{ACKNOWLEDGMENTS}

This paper is part of research studies funded by the Brazilian Research Council (CNPq). 


\section{REFERENCES}

[1] Alencar LH \& Almeida AT. 2008. Multicriteria decision group model for the selection of suppliers. Pesquisa Operacional, 28(2): 321-337.

[2] Almeida AT. 2010. The knowledge and the use of multi-criteria decision aid methods (O conhecimento e o uso de métodos multicritério de apoio a decisão). Book, Federal University of Pernambuco publishing house, Recife, Brazil.

[3] Amid A, Ghodsypour SH \& O’Brien C. 2006. Fuzzy multi-objective linear model for supplier selection in a supply chain. International Journal of Production Economics, 104(2): 394-407.

[4] BARRON FH \& BARRETT BE. 1996. Decision quality using ranked and partially ranked attribute weights. Management Science, 42(11): 1515-1523.

[5] Behzadian M, Kazemzadeh RB, Albadvi A \& Aghdasi M. 2010. PROMETheE: A comprehensive literature review on methodologies and applications. European Journal of Operational Research, 200(1): 198-215.

[6] Belton V \& Stewart TJ. 2002. Multiple criteria decision analysis: An integrated approach. Kluwer Academic Publishers, Boston.

[7] Bevilacqua M, Ciarapica FE \& Giacchetta G. 2006. A fuzzy-QFD approach to supplier selection. Journal of Purchasing and Supply Management, 12(1): 14-27.

[8] Boran FE, Genç S, Kurt M \& AKay D. 2009. A multi-criteria intuitionistic fuzzy group decision making for supplier selection with TOPSIS method. Expert Systems with Applications, 36(8): 11363-11368.

[9] Bottani E \& Rizzi A. 2008. An adapted multi-criteria approach to suppliers and products selection: An application oriented to lead-time reduction. International Journal of Production Economics, 111(2): 763-781.

[10] BRANS JP \& Vincke P. 1985. A preference ranking organization method: The PROMETHEE method for multiple criteria decision-making. Management Science, 31(6): 647-656.

[11] Chou S-Y \& Chang Y-H. 2008. A decision support system for supplier selection based on a strategy-aligned fuzzy SMART approach. Expert Systems with Applications, 34(4): 2241-2253.

[12] Clímaco JN, Antunes CH \& Alves MJG. 2003. Multiobjective Linear Programming: From classical linear programming model to explicit consideration of multiple objective functions (Programação Linear Multiobjectivo: Do modelo de programação linear clássico à consideração explícita de várias funções objetivos). Book, Universidade de Coimbra publishing house, Coimbra, Portugal.

[13] CRUZ JM. 2008. Dynamics of supply chain networks with corporate social responsibility through integrated environmental decision-making. European Journal of Operational Research, 184(3): $1005-1031$.

[14] CRUZ JM. 2009. The impact of corporate social responsibility in supply chain management: Multicriteria decision-making approach. Decision Support Systems, 48(1): 224-236.

[15] De Boer L, Labro E \& Morlacchi P. 2001. A review of methods supporting supplier selection. European Journal of Purchasing and Supply Management, 7(2): 75-89.

[16] De Boer L, VAn der Wegen L \& Telgen J. 1998. Outranking methods in support of supplier selection. European Journal of Purchasing and Supply Management, 4(2-3): 109-118. 
[17] De Boer L \& VAn der Wegen LLM. 2003. Practice and promise of formal supplier selection: A study of four empirical cases. Journal of Purchasing and Supply Management, 9(3): 109-118.

[18] Degraeve Z, Labro E \& Roodhooft F. 2000. An evaluation of supplier selection methods from a Total Cost of Ownership perspective. European Journal of Operational Research, 125(1): 34-59.

[19] DICKSON GW. 1966. An analysis of vendor selection systems and decisions. Journal of Purchasing, 2(1): 5-17.

[20] Dulmin R \& Mininno V. 2003. Supplier selection using a multi-criteria decision aid method. Journal of Purchasing and Supply Management, 9(4): 177-187.

[21] EdWARDS W. 1977. How to use multiattribute utility measurement for social decision making. IEEE Transactions on Systems, Man, and Cybernetics, 7(5): 326-340.

[22] EdWARDS W \& BARRON FH. 1994. SMARTS and SMARTER: Improved simple methods for multiattribute utility measurement. Organizational Behavior and Human Decision Processes, 60(3): $306-325$.

[23] FARRELL A. 1996. Making decisions about sustainability: joining social values with technical expertise. In Technology and society technical expertise and public decisions. Proceedings of the international symposium on technology and society technical expertise and public decisions in Princeton, New Jersey, 1996, 188-197.

[24] Gomes LFAM, Rangel LAD \& Leal Junior MR. 2011. Treatment of uncertainty through the interval smart/swing weighting method: a case study. Pesquisa Operacional, 31(3): 467-485.

[25] Ho W, XU X \& DEY PK. 2010. Multi-criteria decision making approaches for supplier evaluation and selection: A literature review. European Journal of Operational Research, 202(1): 16-24.

[26] Holt GD. 1998. Which contractor selection methodology? International Journal of Project Management, 16(3): 153-164.

[27] Joвim Filho H. 2002. Supply chain of construction industry: a proposal for suppliers' evaluation and selection of materials and components (Cadeias de suprimentos da construção civil: uma proposta para avaliação e seleção de fornecedores de materiais e componentes). Master Degree Thesis, Production Engineering Department, Federal University of Santa Maria, Santa Maria, Brazil.

[28] Keeney RL \& Raiffa H. 1976. Decisions with multiple objectives: Preferences and value tradeoffs. Wiley, New York.

[29] Kirytopoulos K, Leopoulos V, Mavrotas G \& Voulgaridou D. 2010. Multiple sourcing strategies and order allocation: An ANP-AUGMECON meta-model. Supply Chain Management: An International Journal, 15(4): 263-276.

[30] Kull TJ \& TALLURI S. 2008. A supply risk reduction model using integrated multicriteria decision making. IEEE Transactions on Engineering Management, 55(3): 409-419.

[31] LAI G, Li C, SyCARA K \& Giampapa J. 2004. Literature review of multi-attribute negotiations. Technical Report, CMU-RI-TR-04-66, Carnegie Mellon University, Pittsburgh, USA.

[32] LAI GM, Li CH \& SYCARA K. 2006. Efficient multi-attribute negotiation with incomplete information. Group Decision and Negotiation, 15(5): 511-528.

[33] Mustajoki J, HÄMÄLÄINEn RP \& SAlo A. 2005. Decision Support by Interval SMART/SWING - Incorporating Imprecision in the SMART and SWING Methods. Decision Sciences, 36: 317-339. 
[34] Nagurney A, Cruz J, Dong J \& Zhang D. 2005. Supply chain networks, electronic commerce, and supply side and demand side risk. European Journal of Operational Research, 164(1): 120-142.

[35] NG WL. 2008. An efficient and simple model for multiple criteria supplier selection problem. European Journal of Operational Research, 186(3): 1059-1067.

[36] ORdoobadi SM. 2009. Development of a supplier selection model using fuzzy logic. Supply Chain Management: An International Journal, 14(4): 314-327.

[37] Ramanathan R. 2007. Supplier selection problem: Integrating DEA with the approaches of total cost of ownership and AHP. Supply Chain Management: An International Journal, 12(4): 258-261.

[38] RoY B. 1996. Multi-criteria methodology for decision aiding. Kluwer Academic Publishers, Netherlands.

[39] SAATY TL. 1988. The analytical hierarchy process. McGraw-Hill, New York.

[40] Schmidt AS, Jobim Filho H, Jobim MSS, Silva VM, Gobus L, Scapin J \& Bieger F. 2001. Integration of supply chains: materials and components suppliers evaluation system in the construction industry (Integração das cadeias produtivas: Sistema de avaliação de fornecedores de materiais e componentes na indústria da construção civil), working paper, Federal University of Santa Maria, Santa Maria, Brazil.

[41] Szajubok NK, Mota CMM \& Almeida AT. 2006. The use of ElECTRE TRI for sorting inventory in construction industry (Uso do método multicritério ELECTRE TRI para classificação de estoques na construção civil). Pesquisa Operacional, 26(3): 625-648.

[42] TING S-C \& CHO DI. 2008. An integrated approach for supplier selection and purchasing decisions. Supply Chain Management: An International Journal, 13(2): 116-127.

[43] Tuzkaya G, Ozgen A, Ozgen D \& Tuzkaya UR. 2009. Environmental performance evaluation of suppliers: A hybrid fuzzy multi-criteria decision approach. International Journal of Environmental Science and Technology, 6(3): 477-490.

[44] Valois U \& Almeida AT. 2009. Support model for multicriteria decision to outsource productive activities based on SMARTS method (Modelo de apoio à decisão multicritério para terceirização de atividades produtivas baseado no método SMARTS). Produção, 19(2): 249-260.

[45] Verma R \& Pullman ME. 1998. An analysis of the supplier selection process. Omega, 26(6): 739-750.

[46] ViNCKE P. 1992. Multi-criteria decision aid. John Wiley and Sons, Bruxelles.

[47] Weber CA, CurRent JR \& Benton WC. 1991. Vendor selection criteria and methods. European Journal of Operational Research, 50(1): 2-18.

[48] Wu DD, Zhang Y, Wu D \& OLson DL. 2010. Fuzzy multi-objective programming for supplier selection and risk modeling: A possibility approach. European Journal of Operational Research, 200(3): 774-787. 